\title{
Free Time Activities of High School Students: Sports or Video Games?
}

\author{
By Ildikó Balatoni", Henrietta Szépné Varga ${ }^{ \pm}$\& László Csernoch ${ }^{\ddagger}$
}

Data from various national and international surveys show that people in developed countries do not perform enough physical activity, even though it is an essential part of a healthy lifestyle. Young people spend most of their free time watching TV, using IT-tools, including computer games. In recent years, video-game (i.e., e-sports) team competitions have become more and more popular in Hungary, with countless spectators and mass events that further promote this new sport. We were interested in knowing the proportion of free time high school students spend participating in sports and video games, and if the time spent on them is gender specific. The survey was conducted in the Spring of 2018 in Hungary, among high school students. Questions concerned the respective individual's sporting habits and their computer games-related behaviour. While analysing the data, the proportion of time spent on physical activity and video games was also examined and the scope extended to explore the differences between age groups, place of residence, type of school, and genders as well. The questionnaire was filled in by 882 students. Respondents reported to have approximately 3.6 hours of free time on weekdays and 6.6 hours on weekends. Boys reported having half an hour freer time. $86.8 \%$ of the students do sports regularly, with no difference $(p>0.2)$ between the genders. In Hungary, the compulsory system of daily physical education in primary and secondary schools contributes greatly to this purpose, but the passion for and the enjoyment of physical activity is also important. At the same time, we need to be aware of the needs and interests of our children in order to influence their way of life in a positive way

Keywords: free time, physical activity, students, sports, video games

\section{Introduction}

The concept of free time has changed recently (Furlong et al. 2000), and in fact it is not related to time itself anymore, but rather to its use. In the past decade, free time at home has also become a proper form of recreation, which has been made especially attractive by television and computer games (Nagy and Fazekas 2016). Researchers consider it justified that in the case of the present-day youth the forms of free time are no longer determined by the diverse, intelligent ways of experiencing recreation, but by the peculiarity of the modern age, the rushing

\footnotetext{
*Executive Director, Clinical Center, University of Debrecen, Hungary.

${ }^{ \pm}$Quality Management Assistant, Clinical Center, University of Debrecen, Hungary.

${ }^{\ddagger}$ Professor and Head, Department of Physiology, Faculty of Medicine, University of Debrecen, Hungary.
} 
(often virtual) world of information society that triggers quick reactions (Nagy and Fazekas 2016).

In parallel, the lack of physical activity in the Western societies has reached a point that it can be considered an epidemic and can be the basis of a number of non-communicable chronic diseases. Unfortunately, Hungary is one of the countries where adolescent obesity and associated metabolic disorders are the highest in the European Union (Eurostat 2018).

In the course of our research, we conducted a survey on a sample of 882 people in the North Great Plain region of Hungary, among high school students. We studied the matter of how often respondents are doing sports in their free time and how much time they spend on computer games. We were interested in seeing whether or not there are any differences in this respect between students attending different types of high schools, grammar vs. vocational, and between their places of residence, cities $v s$. villages and farms.

\section{Literature Review}

Numerous studies have found that today television and computer use dominate the ways of spending free time in all European countries (Kenyeres and Juhász 2017). According to Eurostat (2018), the proportion of daily internet users in the EU is $95 \%$, while in Hungary is $92 \%$.

Based on the 2016 results of the representative Hungarian Youth Research conducted every four years on a large sample of 12,000 young people (15-29 years old), the role of IT-technology played in the lives of young Hungarians has further increased; while between 2004-2008 home internet access has become common. In 2016 this was also the case with smartphone usage (Székely and Szabó 2017). Now this phenomenon also affects everyday activities from communication to learning and work to free time. The most important tool is the smartphone, which only $31 \%$ of young people in 2012 had use of, whereas by 2016 this ratio reached $85 \%$, and $70 \%$ of the devices were connected to the World Wide Web. In parallel with the wide-spreading of digital devices and the internet, the role of the media in everyday life has also changed, with digital media already present in two-thirds of free time activities.

According to the Eurobarometer data for 2017, almost half (46\%) of the population of the European Union does not conduct any physical activity at all, and only $40 \%$ do sports on a regular basis. Looking at the 15-24-year-old age group, the proportion of non-athletes is $24 \%$, while the proportion of those who conduct physical activity at regular intervals (1-5 times per week) is $62 \%$. On the other hand, the ratio of those practicing physical activity decreases with age (Eurobarometer 2018).

A study concerning 34 different countries, involving more than seventy thousand schoolchildren (Guthold et al. 2010) shows that young people spend more than 3 hours a day with sedentary activities, which are not related to school or to homework. At the same time, $23.8 \%$ of boys and $15.4 \%$ of girls conduct physical activities 5 times a week that last at least sixty minutes. All this is not 
only reflected in a decrease in physical endurance, but also in a more frequent appearance of psychological problems (Vancampfort et al. 2018). Other researchers (Feldman et al. 2003) have found that time spent on physical activity and electronic media usage is not interlinked, however time spent on home work and part-time work reduce the amount of free time that can be spent on sports. Boraccino et al. (2009), as a result of their 32-nation study, have suggested that moderate or more intense physical activity among adolescents is correlated with age, gender and social status, and gender differences move in line with age. At the same time, on-screen activities and regular sports are not competitive factors of each other.

Researchers have pointed out that the risk of depression and anxiety disorders increases in the case of young people who spend more than 2 hours/day of their free time looking at screens (Vandendriessche et al. 2019, Zink et al. 2019), which can be offset by regular physical activity. The use of electronic media in the preschool age could predict a perception of lower self-esteem in later stages (during adulthood) and increase the incidence of emotional problems and inadequate family involvement (Hinkley et al. 2014). Parents having a child under 2 years of age and allowing watching TV, DVD or video for more than 1 hour a day for entertainment or "babysitting" purposes, should at least be conscious about what and how long their children are watching (Zimmerman et al. 2007).

Over the past decade, children's screen time has increased dramatically. Research has shown that screen time (TV, video games, computers, smartphones, etc.) is linked to the consumption of foods containing large amounts of fat and salt, as well as to the consumption of sugary foods and beverages, which coupled with physical inactivity, lead straight to childhood obesity (Mack et al. 2017, Delfino et al. 2018, Hicks et al. 2019, Miguel-Berges et al. 2019, Olds et al. 2019, Zhu et al. 2019).

Insufficient physical activity, too much screen time, inadequate meals and short sleep duration increase the risk of cardiovascular diseases, obesity, and may result in additional health problems (Pereira et al. 2015). In many cases screen activities of many young people also take away from sleep time and looking at screens before going to bed may impair the quality of sleep as well. Insufficient sleep and poor sleep quality sooner or later result in the emotional instability of young people, leading to chronic emotional dysregulation and impaired school performance (Hysing et al. 2015, Xu et al. 2019).

Other researchers investigated the relationship between school performance and physical fitness, with the emphasis on the impacts of screen time (Aguilar et al. 2015). It was found that both parents and teachers should try to influence young people to minimize the negative effects of electronic media.

The role of parents is extremely important in developing a healthy lifestyle concerning their children. Both the behavioral pattern shown in the field of sports and physical activity conducted together, along with family programs are decisive with respect to the development of habits in a later age (Dong et al. 2016, Langoy et al. 2019). Parental effects are also important in developing healthy eating habits and limiting screen time (Frate et al. 2019, Goncalves et al. 2019). In addition, the built environment (i.e., the environment in which people live and work, including 
but not restricted to man-made structures and facilities) also influences the free time spending habits of young people (Kosztin et al. 2017, Balatoni et al. 2018, Bejarano et al. 2019).

Based on this, the question arises whether besides the daily school load how the environmental enrichment of cyberspace will take away time from physical activity and how the increased media consumption created by the information society will shape the free time of school age children.

We were curious as to what kind of sporting habits do young people in our region have and how much time they spend in front of the screen.

\section{Methodology}

The survey was carried out in Hungary, with the contribution of the students of a six-grade grammar school in Debrecen, as well as a four-grade grammar school and a vocational secondary school in Hajdúnánás, respectively, in the spring of 2018.

Hajdúnánás is a town in the North Great Plain region of Hungary, in HajdúBihar county, with a population of 17,059 people, which is $0.17 \%$ of the country's population. It is $40 \mathrm{~km}$ from Debrecen. Its agriculture system is advanced, with the country's largest grain processing plant situated here. The active population is steadily declining, the proportion of people over 65 is increasing, and the under-14 age group is decreasing (aging index - the number of people over 65 compared to the number of 0-14-year-olds, in $\%-129.35 \%)$. The health status of the population, similarly to the respective data from this part of the country, shows disadvantageous statistical results, especially regarding cardiovascular, cancer and alcohol related illnesses and completed suicides (Hajdúnánás Városi Önkormányzat 2018).

Debrecen is Hungary's second largest city and the economic, educational, scientific and cultural center of Hajdú-Bihar County and the North Great Plain region. Its population is 202,402 , that is $2.05 \%$ of the country's population and $38.16 \%$ of the population of Hajdú-Bihar County. The aging index is $130.05 \%$ (Debrecen Megyei Jogú Város 2018). Labor market opportunities are better than in smaller settlements of the region or the county.

First the participating schools were approached then the school officially notified the parents of the students to get their consent. The questionnaires were consequently filled in voluntarily and anonymously, and interviewers were also contributing to the process. Besides our questions concerning socio-demographic data we were also interested in the sporting habits of the individuals. The rest of the questionnaire covered computer game-related behavior, including the time spent on computer games, the gaming platform, and any competition-related goals in this respect. We were also curious as to how much free time young people have on weekdays and weekends, and how their time spent on video games (screen time) and physical activity are divided in their free time, furthermore the difference between the genders. We also analyzed the differences between the age 
groups and whether these parameters are influenced by the place of residence and the type of school.

The completed questionnaires were processed with the EvaSys software (http://www.vsl.hu). When presenting any data, the mean \pm SD is shown in all cases. Differences with $\mathrm{p}<0.05$ were considered significant.

\section{Results}

The questionnaire was completed by 882 respondents, with an average age of $15.9 \pm 1.3$ years (mean \pm SD). $55.4 \%$ of the respondents were girls, $42.6 \%$ were boys; their average age was $16.0 \pm 1.3$ and $15.7 \pm 1.3$ years, respectively.

$54.8 \%$ of the respondents live in Debrecen, in the county seat, $37.3 \%$ live in the neighboring towns, the others live in smaller settlements, villages and farms.

Respondents, based on their own judgment, have an average of $3.6 \pm 1.7$ hours of free time on weekdays and $6.6 \pm 1.7$ hours on weekends (Figure 1).

$50.3 \%$ of the respondents said they used to play computer games, on average $1.9 \pm 1.4$ hours on weekdays, and $3.3 \pm 2.0$ hours on weekends.

$34.1 \%$ of young people play on their mobile phones, $29.0 \%$ on a computer, $19.1 \%$ use video game consoles.

The most popular games are FIFA (15.7\%), PUBG and League of Legends (13.2\% and $13.0 \%$ ), and CS: GO (12.6\%). $7.9 \%$ of the participants play in a competitive way and $2.95 \%$ are members of an e-sports association.

$86.6 \%$ of the respondents said they were doing sports regularly (the term "sports" was defined as continuous physical activity of at least 30 minutes beyond school physical education); concerning frequency $24.1 \%$ of the respondents answered they did sports on a daily basis, $47.1 \%$ marked the answer "2-3 times a week".

When analyzing the aggregate data in terms of the selected sports the most popular ones are running $(22.1 \%)$, cycling $(21.8 \%)$ and conditioning workouts at gyms $(21.2 \%)$.

In the case of non-athletes, the most common causes of inactivity were fatigue and lack of time.

Non-athletes mentioned walking (20\%), cycling (15.5\%) and working around the house (13.8\%) as other forms of physical activity.

\section{Gender Differences}

When analyzing the gender differences, it can be observed that girls reported significantly less free time both on weekdays ( $3.3 \pm 1.5$ hours) and weekends (6.5 \pm 1.8 hours) than boys $(3.9 \pm 1.8$ hours; $6.8 \pm 1.6$ hours) (weekdays: $p<0.001$, weekend: $\mathrm{p}<0.01$; Figure 1A). 
Figure 1. Self-Estimate of Free (A) and Screen Times (B) during Weekdays and Weekends (C) Percentage of those Engaging in Sport Activity at Different Frequencies

A

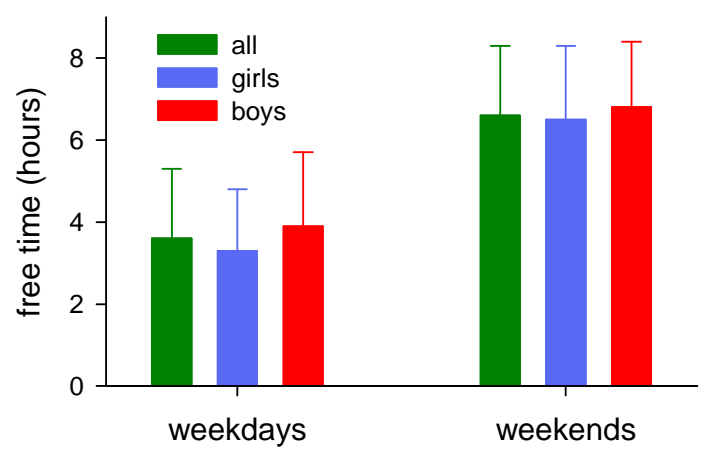

B

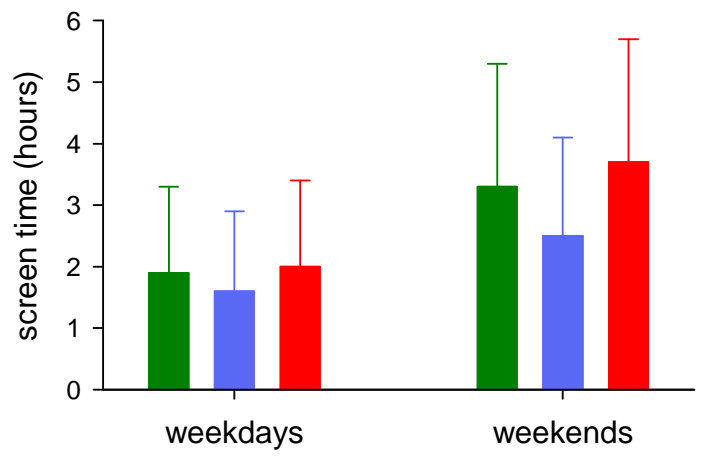

C

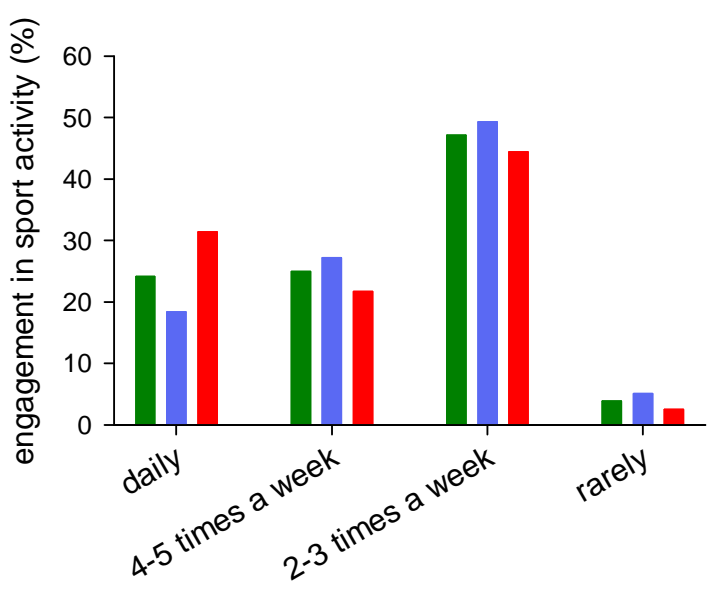

Source: Authors' Compilations.

When asked if they were playing computer games, only $25.6 \%$ of the girls answered yes, compared to boys, $83.8 \%$ of whom answered yes. The difference is clearly $(\mathrm{p}<0.0001)$ significant.

The time spent on computer games is also significantly different (weekdays: $p$ $<0.01$; weekend: $\mathrm{p}<0.001$ ) between the two genders (Figure 1B). While boys spend $2.0 \pm 1.4$ hours on weekdays and $3.7 \pm 2$ hours on weekends exposed to 
electronic screens, girls spend much less, that is $1.6 \pm 1.3$ hours on weekdays and $2.5 \pm 1.6$ hours on weekends.

As far as the platform is concerned, while the most commonly used device is the smartphone in the case of both genders, boys use the computer in the same proportion as the phone. In contrast, the ratio of the second most commonly used device by girls (i.e., the laptop) is just over the half of the ratio of that of the phone.

There was no difference between the genders in terms of the most popular games.

Since the proportion of computer players among girls is much lower than that of boys, the proportion of female members of e-sports associations is also lower than that observed in the case boys. Of the girls participating in competitions only one is a member of an e-sport association, while for boys this value is 25 .

Looking at the matter of sports habits, it can be stated that $85.4 \%$ of girls and $89.5 \%$ of boys do sports on a regular basis. In this respect, there was no detectable difference ( $p>0.2$ ) between the genders, but at the same time concerning the frequency sporting activities, the ratio of girls doing sports daily was significantly lower $(\mathrm{p}<0.001)$.

Among boys, football, conditioning workouts at gyms and cycling, among girls, running, cycling and dancing are the most preferred sports.

There are no differences between girls and boys in the most common causes for not doing sports.

\section{Differences between Age Groups}

There is no significant difference between the age groups in terms of free time (Figure 2). On the other hand, the time spent on playing decreases over the age of 16 , while the proportion of players participating in competitions and members of associations increases with age.

Figure 2. Self-Estimate of Free (A) and Screen Times (B) during Weekdays and Weekends at Different Ages. Horizontal Lines Represent the Average (taken from Figure 1) over the Entire Cohort

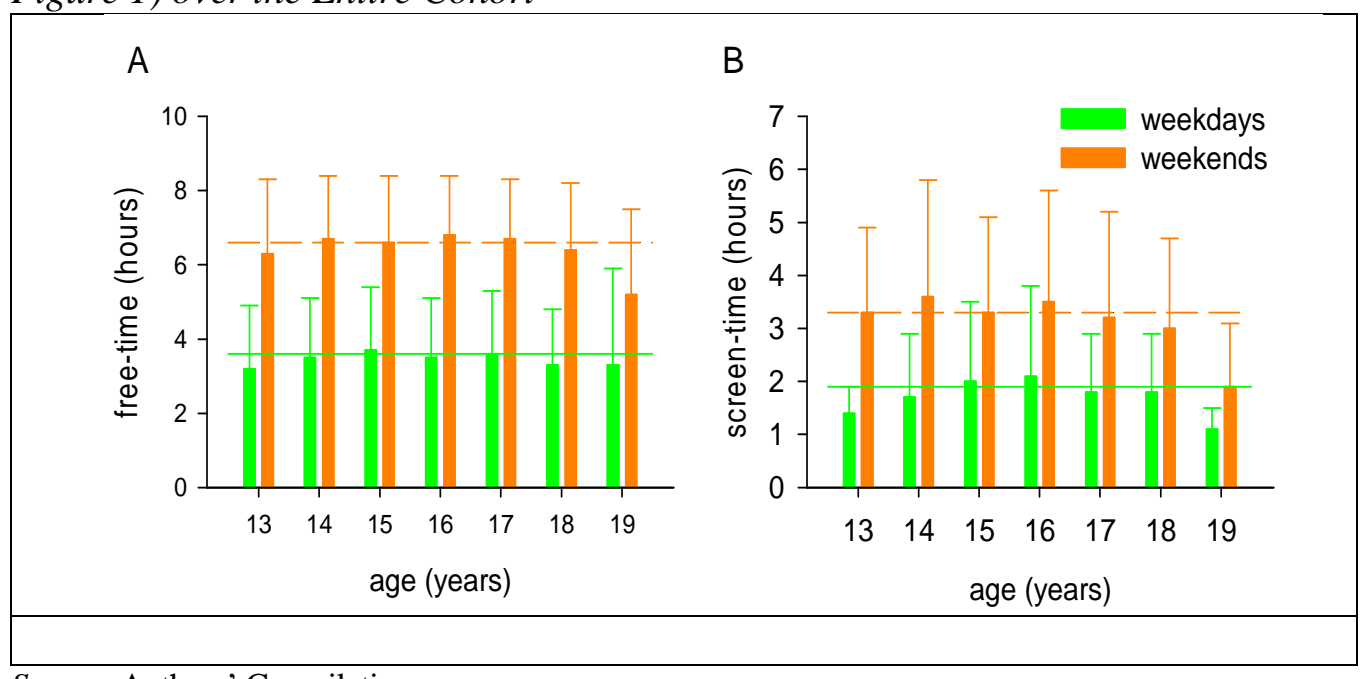

Source: Authors' Compilations. 
The proportion of those doing sports regularly decreases with age (Figure 3), with the response rate of lack of motivation as the reason for not doing sports is increasing.

There is a significant difference between 14- and 18-year-olds concerning regular physical activity $(95.2 \%$ vs. $81.5 \%$; $\mathrm{p}<0.001)$. The most frequently chosen sports do not change depending on age, but it is noticeable that until the age of 14 , the $4^{\text {th }}$ most common sport is swimming, however by the age of 18 , hardly any people remain who do this sport.

Figure 3. Percentage of those Doing Sports Regularly at Different Ages

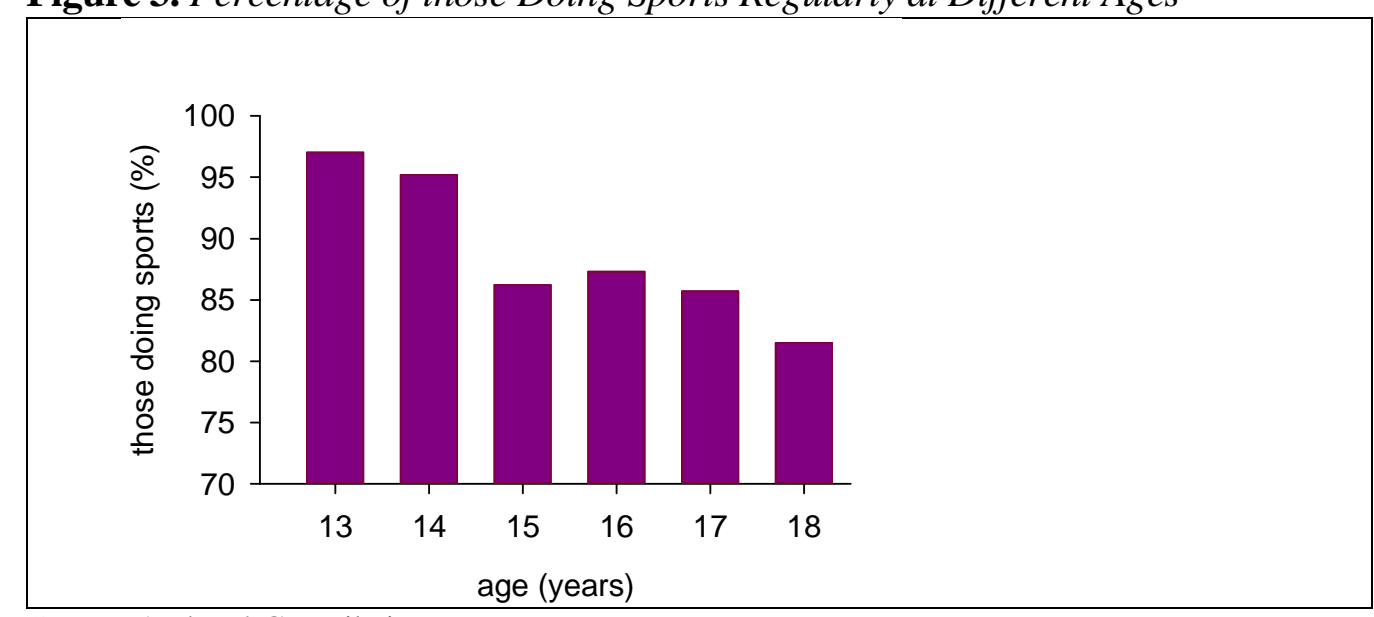

Source: Authors' Compilations.

Differences between School Types

We also compared the answers of students of grammar schools and vocational secondary schools. According to the data, the proportion of girls among grammar school students is higher than in vocational secondary schools $(61.2 \% \mathrm{vs} .44 .6 \%$; $\mathrm{p}$ $<0.001)$. The values clearly show that vocational secondary school students have more free time both on weekdays and on weekends (grammar school: weekdays $3.3 \pm 1.6$ hours, weekend: $6.5 \pm 1.7$ hours; vocational secondary school: weekdays $4.7 \pm 1.6$ hours, weekend $7.1 \pm 1.7$ hours; $p<0.001$; $p<0.001$ ). The proportion of those playing computer games is significantly higher. In spite of this, the time spent in front of the screen is lower than that of their peers (grammar school: weekdays $1.6 \pm 1.1$ hours, weekend: $3.2 \pm 1.9$ hours; vocational secondary school: weekdays $2.6 \pm 1.9$ hours, weekend $3.8 \pm 2.2$ hours; $\mathrm{p}<0.001$ and $\mathrm{p}<0.01$, respectively).

The proportion of those regularly doing sports is significantly lower among vocational secondary school students $(89.5 \%$ vs. $75.3 \%$; p <0.001). In the case of the selected sports, the most popular one concerning vocational secondary school students is football versus cycling which is in first place in the case of grammar school students. 


\section{Residential Differences}

Among those who have filled in the questionnaire, we can find people living in county seats (Debrecen), small towns, villages and farms as well. Analyzing the data obtained, it can be concluded that people living in Debrecen reported less free time both on weekdays and on weekends (weekdays: Debrecen $3.6 \pm 1.7$ hours vs. other $4.0 \pm 1.7$ hours; $\mathrm{p}<0.01$; weekend: Debrecen $6.5 \pm 1.7$ hours $v s$. other $6.8 \pm$ 1.7 hours, $p<0.05)$. It is assumed that this is due to the higher number of private lessons of Debrecen-based students and the wider range of study groups offered by the respective school.

Among the respondents there were 6 people who live on a farm. Although it is not possible to draw statistical conclusions due to the low number of respondents, we would like to note that their answers differed considerably from the others on several issues. Of the people living on a farm, 5 people said they were playing computer games on a regular basis, but in their case only one person had a smartphone, the others played on the computer. They do not have laptops, video game consoles, or tablets. In contrast to the others' $87.3 \%$ ratio, only twothirds of those living on a farm are doing sports. In addition to the lack of time and fatigue, lack of money and health are also among the reasons for not doing sports. In the case of other activities, working around the house and physical work dominate in the answers in contrast to the answers of the others' walking and cycling.

\section{Characteristics of Competitive Players}

Of the respondents 70 people said they were playing computer games on a competitive level. If comparing their answers with others' (Figure 4), it is noticeable that they have more free time on weekdays (competitors: weekdays 4.2 \pm 1.9 hours, others: weekdays $3.5 \pm 1.6$ hours; $p<0.001$ ). Their time spent in front of the screen also shows a much higher value (competitors: weekday $2.7 \pm 1.9$ hours, others: weekdays $1.8 \pm 1.3$ hours; $\mathrm{p}<0.001$ ).

If looking at weekends - although the competitors report a bit freer time in this case also - the difference is not significant (competitors: weekend $6.9 \pm 1.7$ hours, others: $6.6 \pm 1.7 ; p>0.2$ ). At the same time, their time spent in front of the screen is significantly higher than that of the others during this period (competitors: weekend $4.7 \pm 2.2$ hours; others: $3.2 \pm 1.9 ; \mathrm{p}<0.001$ ). In the light of this it is surprising that $89.6 \%$ of them do sports regularly, $50 \%$ of them do so on a daily basis. 
Figure 4. Self-Estimate of Free (A) and Screen Times (B) of Competitive VideoGame Players and Others during Weekdays and Weekends

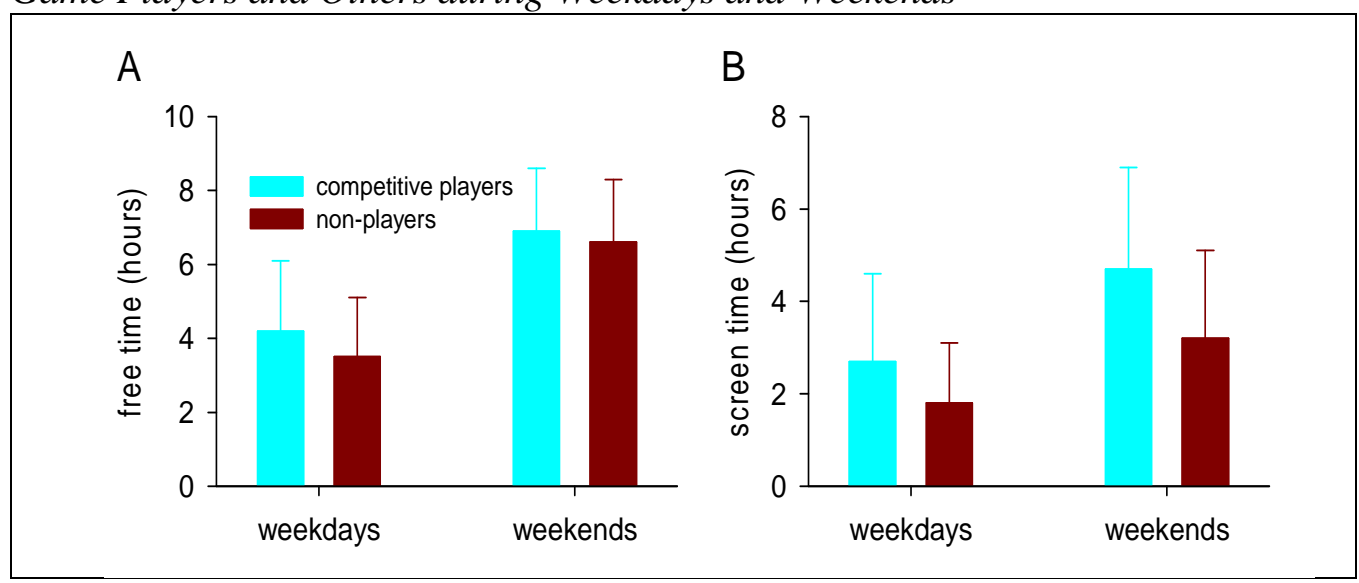

Source: Own Compilation.

\section{Discussion}

During our research, we interviewed 882 high school students in North-East Hungary about their computer gaming and sporting habits. $50.3 \%$ of the respondents spend several hours in front of the screen every day, and -based on their own judgment- spend half of their daily free time playing computer games, however $86.6 \%$ of them also do sports on a regular basis. There are significant gender differences among computer gamers: compared to $83.6 \%$ of boys, only $25.6 \%$ of girls said they used to play such games. In the case of answers concerning sports-related questions, we found a significant difference between the genders regarding the chosen sport and the frequency of doing sports.

Among younger people (13-16 years old) the percentage of gamers is higher, but the time spent playing games does not show age-dependence. Similar to other international studies (e.g., Eurobarometer 2018), the proportion of those doing sports regularly decreases with age, while the lack of motivation increases.

Vocational secondary school students typically reported more free time than their grammar school counterparts, and the percentage of gamers among them was also higher.

E-sports competitors have more free time and of course spend much more time in front of the screen than others. At the same time, the proportion among them doing sports regularly is the same.

As stated in the WHO strategy (Waxman 2004), unhealthy nutrition and physical inactivity have reached a magnitude today that is responsible for $60 \%$ of global deaths. These two factors affect health both together and on individual level. The most common element of a sedentary lifestyle is the time spent on mobile phones and computers.

Adult habits are established at a young age, which is why adolescent participation in regular sports activities reduces the likelihood of developing unhealthy lifestyle habits in adulthood (Torsveit et al. 2018). For this reason, it is 
very important for young people to experience healthy lifestyle habits in their surroundings and thus form these for themselves (González-Valero 2019).

Adolescence is the period when a young child becomes an adult, and due to hormonal changes, he/she is prone to great emotional fluctuations and changes in the nervous system in addition to physical transformation. This period is characterized by frequent stressful situations and feelings, as a result of which young people are emotionally vulnerable (Költő and Zsiros 2013).

If the risks at this stage of life are further increased by habits harmful to health, the likelihood of developing diseases will continue to grow also. Unhealthy lifestyle, such as physical inactivity, inadequate nutrition, long time spent in front of the screen, lack of sleep all emerge as a global trend in the world, and unfortunately there is an increase in the likelihood of cardiometabolic diseases, obesity and further psychological illnesses among children as well (Pereira et al. 2015, Mack et al. 2017).

Research related to this matter unequivocally emphasizes the importance of regular sports at an early age (Dumith et al. 2011, Guthold et al. 2010), highlighting the significance of sports in the case of genetic factors that make one disposed to obesity (Celis-Morales et al. 2019).

\section{Conclusions}

Our results clearly show, in line with previous observations, that high school students, especially boys, spend a significant amount of their free time in front of a television or computer screen. An import component of this is either participating in or playing video games or watching e-sports events. This raises several concerns. First and foremost, the time for other free time activities, including physical exercise, is reduced with all the health-related consequences. Second, when sitting in front of the screen people usually pick up unhealthy eating habits as well, namely, drinking sugary beverages and consuming large amounts of food with fat and salt again contributing as risk factors for the non-communicable chronic diseases. Finally, as evidenced from our data, some of the most popular computer games are those which include combat and fighting the extensive use of which might result in behavioral disorders.

One of the most important platforms for solving the problem analyzed above could by the family. Although not assessed here, parental responsibility in shaping a child's lifestyle is indisputable. Other important factors are physical education in schools, everyday physical activity organized within the school, and the passion for exercise transmitted from educators and PE teachers to children. The built environment also has a significant impact on shaping the free time habits of young people. For this reason, it can be concluded that it is us, the adults of today who are shaping the adult habits of future generations. It is the responsibility of all of us to let children grow up to healthy adults. However, cross-border cooperation all over the EU is needed to achieve comprehensive results. 


\section{Acknowledgments}

This work was supported by the EFOP-3.6.2-16-2017-00003 project. The project is co-financed by the European Union and the European Social Fund.

\section{References}

Aguilar MM, Vergara FA, Velásquez EJA, Marina R, García-Hermoso A (2015) Screen time impairs the relationship between physical fitness and academic attainment in children. Journal de Pediatria 91(4): 339-345.

Balatoni I, Kosztin N, Csernoch L, Papp Á, Balla Gy (2018) A gyermek- és fiatalkori úszás helyzete Magyarországon. (The state of child and adolescence swimming in Hungary). Sportorv. Szle 59(1): 19-26.

Bejarano CM, Carlson JA, Cushing CC, Kerr J., Saelens, BE., Frank, LD., Glanz, K., Cain, KL., Conway, TL., Sallis JF (2019) Neighborhood built environment associations with adolescents' location-specific sedentary and screen time. Health Place 56(Mar): 147-154.

Borraccino A, Lemma P, Lannotti R, Zambon A, Dalmasso P, Lazzeri G et al. (2009) Socio-economic effects on meeting PA guidelines: comparisons among 32 countries. Medicine and Science in Sports and Exercise 41(4): 749-756.

Celis-Morales CA, Lyall DM, Petermann F, Anderson J, Ward J, Iliodromiti S et al. (2019) Do physical activity, commuting mode, cardiorespiratory fitness and sedentary behaviours modify the genetic predisposition to higher BMI? Finding from a UK Biobank study. International Journal of Obesity 43(8): 1526-1538.

Debrecen Megyei Jogú Város KultúrÁsz Közhasznú Egyesület (2018) Debrecen megyei jogú város önkormányzata helyi esélyegyenlöségi programja 2018-2023. (Local equal opportunity program of the city council of Debrecen 2018-2023). Retrieved from: from: https://bit.ly/2zGcDvT.

Delfino LD, Dos Santos Silva DA, Tebar WR, Zanuto EF, Codogno JS, Fernandes RA et al. (2018) Screen time by different devices in adolescents: association with physical inactivity domains and eating habits. The Journal of Sports Medicine and Physical Fitness 58(3): 318-325.

Dong F, Howard AG, Herring AH, Thompson AL, Adair LS, Popkin BM (2016) Parentchild associations for changes in diet, screen time, and physical activity across two decades in modernizing China: China health and nutrition survey 1991-2009. International Journal of Behavioral Nutrition and Physical Activity 13(118).

Dumith SC, Gigante DP, Domingues MR, Kohl HW (2011) Physical activity change during adolescence: a systematic review and a pooled analysis. International Journal of Epidemiology 40(3): 685-698.

Eurobarometer (2018) Special Eurobarometer 472, sport and physical activity. Retrieved from: https://bit.ly/2W44RU2. [Accessed 18 April 2019].

Eurostat (2018) Retrieved from: https://bit.ly/3aKY86P. [Accessed 18 April 2019].

Feldman DE, Barnett T, Shrier I, Rossignol M, Abenhaim L (2003) Is physical activity differentially associated with different types of sedentary pursuits? Archives of Pediatrics and Adolescent Medicine 157(8): 797-802.

Frate N, Jenull B, Birnbacher R (2019) Like father, like son. Physical activity, dietary intake, and media consumption in pre-school-aged children. International Journal of Environmental Research and Public Health 16(3): 306. 
Furlong A, Stalder B, Azzopardi A (2000) Vulnerable youth: perspectives on vulnerability in education, employment and leisure in Europe - European youth trends 2000. Strasbourg: Council of Europe Publications.

Goncalves WSF, Byrne R, Viana MT, Trost SG (2019) Parental influences on screen time and weight status among preschool children from Brazil: a cross-sectional study. International Journal of Behavioral Nutrition and Physical Activity 16 (1): 27.

González-Valero G, Ubago-Jiménez JL, Ramírez-Granizo IA, Puertas-Molero P (2019) Association between motivational climate, adherence to Mediterranean diet, and levels of physical activity in physical education students. Behavioral Sciences 9(4): 37.

Guthold R, Cowan MJ, Autenrieth CS, Kann L, Riley LM (2010) Physical activity and sedentary behavior among school children: a 34-country comparison. Journal of Pediatrics 157(1): 43-49.

Hajdúnánás Városi Önkormányzat (2018) Helyi esélyegyenlöség program. Hajdúnánás városi ökormányzat képviselö-testület. (Local equal opportunity program of the council of Hajdunánás). Retrieved from: https://bit.ly/2ShmiPE.

Hicks K, Jilcott-Pitts S, Lazorick S, Fang X, Rafferty A (2019) Examining the association between screen time, beverage and snack consumption, and weight status among Eastern North Carolina youth. North Carolina Medical Journal 80(2): 69-75.

Hinkley T, Verbestel V, Ahrens W, Lissner L, Molnár D, Moreno LA et al. (2014) Early childhood electronic media use as a predictor of poorer well-being - A prospective cohort study. JAMA Pediatrics 168(5): 485-492.

Hysing M, Pallesen S, Stormark KM, Jacobsen R, Lundervold AJ, Sivertsen B (2015) Sleep and use of electonic devices in adolescence: results from a large populationbased study. BMJ Open 5(1)

Kenyeres AZ, Juhász E (2017) A kulturális közfoglalkoztatottak szabadidős kulturális aktivitásai, 2017. (Free time cultural activity of public employees from the cultural sector, 2017). Kulturális Szemle. Retrieved from: https://bit.ly/35h1kFV. [Accessed 18 April 2019].

Költő A, Zsiros E (2013) Serdülők lelki egészsége - A magyar iskoláskorú fiatalok mentális egészségének alakulása 2002 és 2010 között. (Mental health of adolescence - The change in mental health of school age children between 2002 and 2010) Education 2: 187-200.

Kosztin N, Tözsér J, Csernoch L, Balatoni I (2017) Reasons for and obstacles to cycling in opinions of residents of Debrecen, Hungary. Apstract 11(3-4): 53-60.

Langoy A, Smith ORF, Wold B, Samdal O, Haug EM (2019) Associations between family structure and young people's physical activity and screen time behaviors. BMC Public Health 19(1): 433.

Mack I, Bayer C, Schäffeler N, Reiband N, Brölz E, Zurstiege G et al. (2017) Chances and limitations of video games in the fight against childhood obesity - A systematic review. European Eating Disorders Review 25(4): 237-267.

Miguel-Berges ML, Santaliestra-Pasias AM, Mouratidou T, De Miguel-Etayo P, Androutsos O, De Craemer M et al. (2019) Combined longitudinal effect of physical activity and screen time on food and beverage consumption in european preschool children: the toybox-study. Nutrients 11(5): 1048.

Nagy Á, Fazekas A (2016) Szabad és még szabadabb idők. (Free and even freer times) In A Nagy, L Székely (Eds), NEGYEDSZÁZAD - Magyar Ifjúság 2012. Luvenis Ifjúságszakmai Mühely - ISZT Alapítvány - Excenter Kutatóközpont - Új Ifjúsági Szemle Alapítvány. Retrieved from: from: https://bit.ly/2KIbDcQ. 
Olds T, Maher C, Dumuid D (2019) Life on holidays: differences inactivity composition between school and holiday periods in Australian children. BMC Public Health 19(2): 450.

Pereira S, Katzmarzyk P, Gomes TN, Borges A, Santos D, Souza M et al. (2015) Profiling physical activity, diet, screen and sleep habits in Portuguese children. Nutrients 7(6): 4345-4362.

Székely L, Szabó A (2017) Magyar ifjúságkutatás 2016 - Az ifjúságkutatás első eredményei. (Hungarian youth research 2016 - First results of youth research). Budapest: Új Nemzedék Központ. Retrieved from: https://bit.ly/3cQbX52.

Torstveit MK, Johansen BT, Haugland SH, Stea TH (2018) Participation in organized sports is associated with decreased likelihood of unhealthy lifestyle habits in adolescents. Scandinavian Journal of Medicine Science in Sports 28(11): 2384-2396.

Vancampfort D, Stubbs B, Firth J, Van Damme T, Koyanagi A (2018) Sedentary behavior and depressive symptoms among 67,077 adolescents aged 12-15 years from 30 lowand middle-income countries. International Journal of Behavioral Nutrition and Physical Activity 15(73).

Vandendriessche A, Ghekiere A, Van Cauwenberg J, De Clercq B, Dhondt K, DeSmet A et al. (2019) Does sleep mediate the association between school pressure, physical activity, screen time, and psychological symptoms in early adolescents? A 12country study. International Journal of Environmental Research and Public Health 16(6): 1072.

Waxman A (2004) WHO global strategy on diet, physical activity and health. Food and Nutrition Bulletin 25(3): 292-302.

Xu F, Adams SK, Cohen SA, Earp JE, Greaney ML (2019) Relationship between physical activity, screen time, and sleep quantity and quality in US adolescents aged 16-19. International Journal of Environmental Research and Public Health 16(9): 1524.

Zhu Z, Tang Y, Zhuang J, Liu Y, Wu X, Cai Y et al. (2019) Physical activity, screen viewing time, and overweight/obesity among Chinese children and adolescents: an update from the 2017 physical activity and fitness in China - the youth study. BMC Public Health 19(1): 197.

Zimmerman FJ, Christakis DA, Meltzoff AN (2007) Television and DVD/video viewing in children younger than 2 years. Archives of Pediatrics and Adolescent Medicine 161(5): 473-479.

Zink J, Belcher BR, Kechter A, Stone MD, Leventhal AM (2019) Reciprocal associations between screen time and emotional disorder symptoms during adolescence. Preventive Medicine Reports 13 (Jan): 281-288. 